\title{
Comparison of Severity Scoring Systems in Community-Acquired Pneumonia
}

\author{
İbrahim Onur Alıcl ${ }^{1}$, Nermin Çapan², Arzu Ertürk², Sema Canbakan² \\ ${ }^{1}$ Lung Transplant Center, Türkiye Yüksek İhtisas Training and Research Hospital, Ankara \\ ${ }^{2}$ Clinic of Chest Diseases, Atatürk Chest Diseases and Chest Surgery Training and Research Hospital, Ankara
}

\begin{abstract}
Objective: The aim of this study was to compare the ability of CURB-65, pneumonia severity index and SMART-COP systems to predict 30-day mortality and the need for intensive respiratory and vasopressor support (IVRS).

Methods: We included 84 cases with community acquired pneumonia (CAP) and followed up for 30 days. The scores were calculated at admission and associated with the 30-day mortality and the need for intensive respiratory and vasopressor support.

Results: The mean age of patients was $58.6 \pm 18.7$ years. The 30 -day mortality level for CAP was $7.1 \%$. Fourteen of 84 patients (16.7\%) with CAP were followed in ICU. The area under curve (AUC) values of the three systems (CURB-65, PSI, and SMART-COP) for 30-day mortality
\end{abstract} were $0.89,0.89$ and 0.91 , respectively, and for the need for IRVS was $0.88,0.91$ and 0.93 , respectively.

Conclusion: The three systems accurately detected the need for IRVS and the 30-day mortality, but none individually demonstrated any advantage over the others.

Keywords: Community-acquired pneumonia, intensive care mortality, severity scores

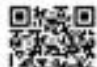

Received Date: 06.07.2014 Accepted Date: 18.09.2014 Available Online Date: 13.02.2015

Address for correspondence İbrahim Onur Alıcı, Lung Transplant Center, Türkiye Yüksek İhtisas Training and Research Hospital, Ankara, Turkey

E-mail: ioalici@hotmail.com

The study was performed in Atatürk Chest Diseases and Thoracic Surgery Education and Research Hospital. This study has been orally presented in the $34^{\text {th }}$ National Congress of Turkish Respiratory Society (Çeşme, Izmir, October 6-10, 2012). 4.0 International License.

DOI: 10.5152/ejp.2014.68077

-Available online at www.eurasianjpulmonol.com

\section{INTRODUCTION}

Community-acquired pneumonia (CAP) is one of the leading causes of high health care cost, hospitalization, and death (1-8). The incidence of CAP in the United States is reported as 5.6 million cases per year, with 915,000 classified as older patients. A total of 1.1 million of these cases required hospitalization, and this number seems to be increasing with time (9-11). CAP together with influenza is the seventh leading cause of mortality in the USA. Therefore, the assessment of disease severity is of crucial importance $(12,13)$. In our country, lower respiratory tract infections are the fifth leading cause of mortality, and they account for $4.2 \%$ of all deaths (1). There are a number of severity assessment tools, of which scoring systems are the most cost effective and easy to use. In our study, we compared the yields of three scoring systems (CURB-65, pneumonia severity index, and SMART-COP) in predicting 30-day mortality and the need for intensive respiratory and vasopressor support (IRVS).

\section{METHODS}

We prospectively analyzed 84 patients who were admitted to outpatient clinics and emergency rooms between May 1, 2009 and April 30, 2010 and who were diagnosed with CAP. The exclusion criteria are listed in Table 1. The demographic characteristics; comorbidities; physical examination, imaging, and laboratory findings; together with some important factors for treatment strategies were noted. Arterial blood gas sampling was performed in patients whose oxygen saturation was $\leq 90 \%$ with a pulse oximeter ( $\leq 93 \%$ in patients $<50$ years old) (13). Sputum smears with gram stain and culture and blood cultures were obtained from hospitalized patients. The serum procalcitonin levels, urine Legionella antigen levels, and PCR for H1N1 (nasopharyngeal smear) were studied in the indicated patients. The patients received treatment according to the national CAP guidelines (14) and were followed up for 30 days. At admission, the scores of the three systems were calculated and classified (Tables 2-4) and the results were associated with the 30-day mortality and the need for IRVS. The patients in whom invasive mechanical ventilation was indi- 
cated and in whom the systolic blood pressure stayed below $90 \mathrm{mmHg}$ despite proper intravenous fluid resuscitation were followed-up in the intensive care unit (ICU). These criteria were defined as the need for IRVS.

\section{Statistical Analyses}

Statistical analyses were performed with Statistical Package for the Social Sciences for Windows 15.0 (SPSS Inc., Chicago, IL, USA), and single variables were compared with the Chi-square test. The yields of the three scoring systems were calculated and compared with receiver operating curve (ROC) analyses.

\section{Table 1. Exclusion criteria}

\section{$<18$ years old}

History of nursing at home or hospitalization longer than $24 \mathrm{~h}$ in the last 90 days

Patients received chemotherapy and/or radiotherapy in the last 30 days

Active tuberculosis

Cystic fibrosis

HIV infected

Patients receiving routine hemodialysis

Homeless people
This study was approved by The Ethics Committee of our institute, and a written informed consent was obtained from every patient.

\section{RESULTS}

Eighty-four patients were enrolled in the study. The mean age of these patients was $58.6 \pm 18.7$ years, and demographic characteristics, clinical findings, and follow-up data are presented in Table 5.

Fourteen of the 84 patients (16.7\%) with CAP were followed-up in the ICU. Twelve patients $(85.7 \%)$ received invasive mechanical ventilation,

Table 3. CURB-65 system (12)

\section{Point}

Confusion

BUN $>20 \mathrm{mg} / \mathrm{dL}$

Respiratory rate $>30$ breaths/min

Systolic hypotension ( $<90 \mathrm{mmHg}$ )

Age $\geq 65$

Group 1: 0 and 1 point

Group2: 2 points

Group 3: $\geq 3$ points

BUN: Blood urea nitrogen

Table 2. Pneumonia Severity Index (11)

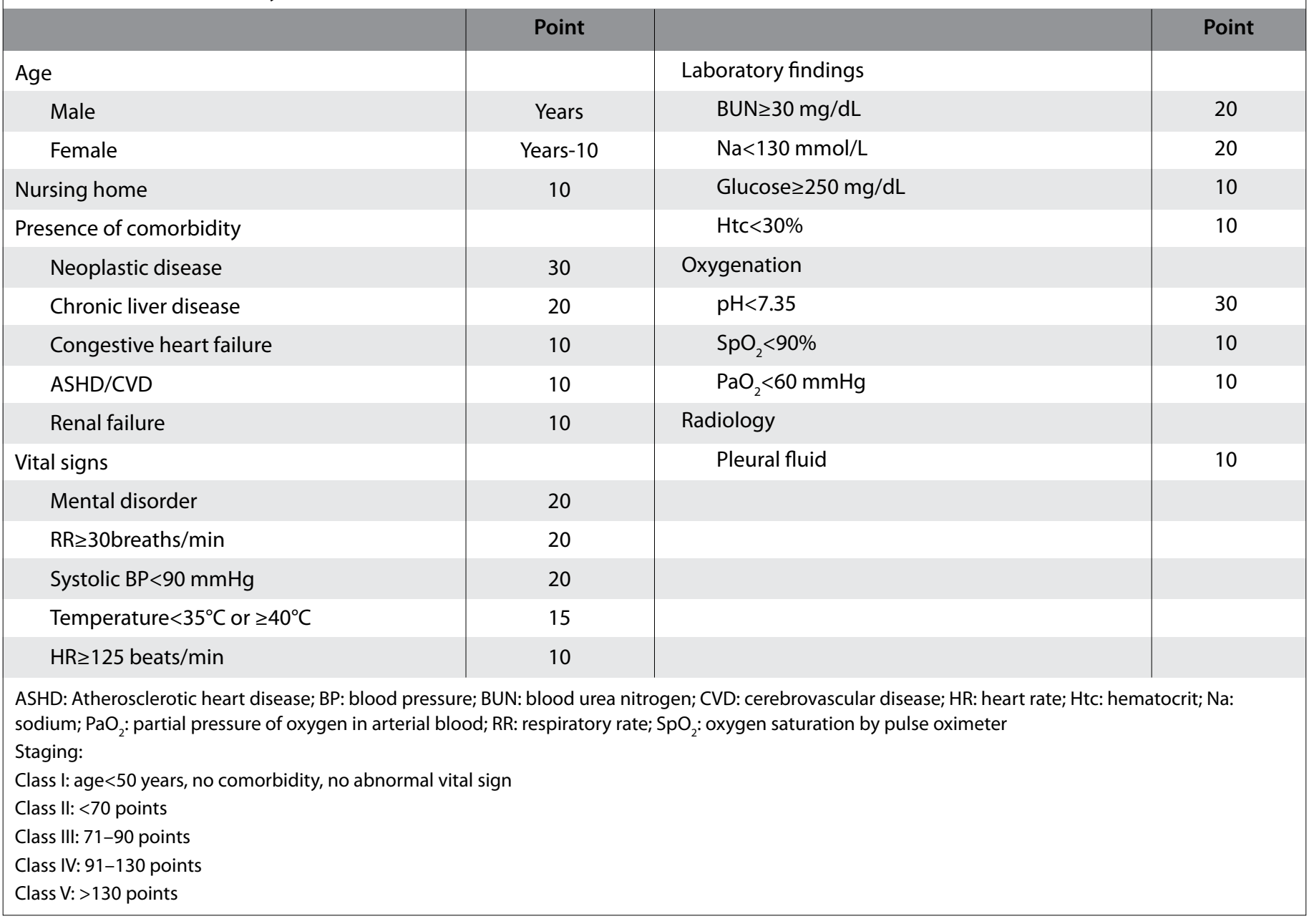




\begin{tabular}{|c|c|}
\hline & Point \\
\hline Systolic blood pressure $<90 \mathrm{mmHg}$ & 2 \\
\hline Multilobar infiltrates & 1 \\
\hline Serum albumin level $<3.5 \mathrm{~g} / \mathrm{dL}$ & 1 \\
\hline Respiratory rate (breaths/min) & 1 \\
\hline \multicolumn{2}{|l|}{$\geq 25$ (age $\leq 50)$} \\
\hline \multicolumn{2}{|l|}{$\geq 30($ age $>50)$} \\
\hline Heart rate $\geq 125$ beats $/ \mathrm{min}$ & 1 \\
\hline Confusion (new onset) & 1 \\
\hline Hypoxemia & 2 \\
\hline \multicolumn{2}{|c|}{$\mathrm{SpO}_{2} \leq 93 \%$ or $\mathrm{PaO}_{2}<70 \mathrm{mmHg}$ or $\mathrm{PaO}_{2} / \mathrm{FiO}_{2}<333(\mathrm{age} \leq 50)$} \\
\hline \multicolumn{2}{|c|}{$\mathrm{SpO}_{2} \leq 90 \%$ or $\mathrm{PaO}_{2}<60 \mathrm{mmHg}$ or $\mathrm{PaO}_{2} / \mathrm{FiO}_{2}<250($ age $>50$} \\
\hline Arterial $\mathrm{pH}<7.35$ & 2 \\
\hline $\begin{array}{l}\text { Group 1: 0-2 points } \\
\text { Group 2: 3-4 points } \\
\text { Group 3: 5-6 points } \\
\text { Group 4: } \geq 7 \text { points }\end{array}$ & \\
\hline
\end{tabular}

and vasopressor support was needed for 3 patients (21.4\%). Nine patients (64.2\%) were immediately hospitalized in the ICU after admission, and 5 of them (35.8\%) were transferred from the general wards.

The 30-day mortality for CAP was $7.1 \%$ (6 cases), and all these patients were followed-up in the ICU with mechanical ventilation support. No mortality occurred in the patients who received vasopressor support.

The number of patients within the groups of the three scoring systems is shown in Table 6. All the patients followed up in the ICU were in classes IV and V according to PSI, and none of the patients in classes I, II, and III needed IRVS. However, according to the CURB-65 score, $35.7 \%$ of the cases followed-up in the ICU were in groups 1 and 2. The patients in group 3 and 4 according to the SMART-COP system constituted $92.8 \%$ of the ICU patients, and system scores $\geq 3$ points were related to a predicted ICU stay of $100 \%$.

All the patients who died within 30 days were in PSI class V. Five of these patients were in the SMART-COP group 4, and one was in group 3. Five patients (31.3\%) in CURB-65 group 3 and one patient in group 2 eventually died.

The ROC analyses revealed that the three systems effectively predicted the 30-day mortality and the need for IRVS ( $p<0.01$ and $p<0.01$, respectively). None of the systems individually demonstrated any advantage over the others (Figure 1,2). The comparison of the scores is summarized in Tables 7 and 8.

\section{DISCUSSION}

The management of CAP requires an accurate prediction of the severity of the disease. The mortality level of CAP is approximately $1.5 \%$ and increases to $15.4 \%$ for severe disease that are followed-up in the ICU (15-17). In our study, the 30-day mortality was $7.1 \%$ in the studied population and $42.8 \%$ in the patients who were followed-up in the ICU. Mortality increases in the hospitalized cases (18).

In an Australian study, $10.3 \%$ of the patients needed IRVS (13), whereas in our study, this value was $16.7 \%$. The values for the 30 -day mortality and the need for IRVS in our study were high compared with other studies but seem closer to the values from studies using scoring systems $(13,15-18)$. This result may be attributed to the use of inclusion criteria. In practice, pulmonologists may consider social factors (e.g., homeless people) into the hospitalization criteria leading to hospitalized patients with decreased disease severity and mortality. However, as we excluded such cases, our study population may consist of more severely diseased patients. Additionally, we had a relatively higher number of patients with pulmonary diseases such as chronic obstructive pulmonary disease (COPD). This would have effect on the need for respiratory support. As we know, the need for invasive mechanical ventilation is higher in patients having COPD complicated with pneumonia (19). Additionally, as a tertiary care hospital, the referral of patients with severe disease increased the number of patients who required ICU care.

A study investigating the microbiological etiology of CAP from our country reported an etiology in $62.8 \%$ of the cases (20), and Streptococcus pneumoniae constituted $19.2 \%$ of them. In our study, we showed an etiology in $46.5 \%$ of the patients, and furthermore, S. pneumoniae was the most common bacteria with an etiology of $25.6 \%$.

The PSI and CURB-65 systems were designed to predict CAP mortality; however, they are less effective in predicting the need for IRVS $(21,22)$. However, the SMART-COP system was developed in a study to investigate the need for IRVS (13). There are conflicting results between some studies on the PSI and CURB-65 systems regarding which method is superior for predicting mortality $(15,23-26)$. Many authors reported a continued reliance on clinical judgment (27). Some studies revealed that PSI is better in young and otherwise healthy people, whereas the CURB-65 system works well in older patients and cases of severe disease $(11,12,28)$. In another study, the sensitivity, specificity, and positive and negative predictive values of PSI (classes IV and V) on predicting mortality were 95\%, 49\%, 21\%, and 99\%; those of PSI (class V) were 50\%, 92\%, 29\%, and 92\%; and those of CURB- 65 ( $\geq 2$ points) were $50 \%, 75 \%, 22 \%$, and $91 \%$, respectively (29). Davis et al. enrolled 184 patients with CAP in their study and found that $38(21 \%)$ patients needed IRVS and $18(10 \%)$ died within 30 days. The sensitivity of the SMART-COP system ( $\geq 3$ points) in predicting the need for IRVS and the 30-day mortality was $71 \%$ and $67 \%$, respectively. Additionally, the report stated that SMARTCOP underestimates the severity of CAP within this population (30). In comparison with other studies, the area under the curve (AUC) value of the SMART-COP system on predicting mortality in our study was found to be higher (0.91 vs. 0.69) (31). No mortality was detected in PSI classes I-III and a SMART COP value of $<3$ points; however, one patient died in the CURB-65 group 2, indicating that the 30-day mortality within this group was $6.25 \%$. 


\begin{tabular}{|c|c|c|c|}
\hline Mean age (years) & $58.6 \pm 18.7$ & Erythrocyte sedimentation rate $\geq 20 \mathrm{~mm} / \mathrm{h}$ & $51 / 62(82.3)$ \\
\hline Age $>50$ years & $61(72.6)$ & Multilobar infiltration on chest roentgenogram & $39(46.4)$ \\
\hline $\operatorname{Sex}(M / F)$ & $53 / 31$ & Pleural fluid on chest roentgenogram & $18(21.4)$ \\
\hline Cerebrovascular disease & $3(3.6)$ & Streptococcus pneumoniae & $10 / 39(25.6)$ \\
\hline Congestive heart failure & $11(13.1)$ & Pseudomonas aeruginosa & $4 / 39(10.2)$ \\
\hline Chronic renal failure & $8(9.5)$ & Methicillin resistant Staphylococcus aureus & $2 / 39(5.1)$ \\
\hline History of pneumonia in last year & $3(3.6)$ & Positive H1N1 PCR & $2 / 9$ \\
\hline Alcohol consumption & $3(3.6)$ & The need for IRVS & $14(16.7)$ \\
\hline Malnutrition (Body mass index<17 kg/m²) & $16(19)$ & Patients received invasive mechanical ventilation & $12(14.3)$ \\
\hline Antibiotic usage before admission & $20(23.8)$ & Patients received vasopressor support & $3(3.6)$ \\
\hline History of viral disease before admission & $11(13.1)$ & 30-day mortality & $6(7.1)$ \\
\hline Clinical findings & & Severity scores & \\
\hline Confusion & $15(17.9)$ & CURB-65 groups & \\
\hline Temperature $<35^{\circ} \mathrm{C}$ or $\geq 40^{\circ} \mathrm{C}$ & $42(50)$ & 1 & $52(61.9)$ \\
\hline Hypoxemiac & $40 / 41(97.6)$ & III & $8(9.5)$ \\
\hline $\mathrm{PaO}_{2} / \mathrm{FiO}_{2}<250$ & $12 / 41(29.2)$ & IV & $18(21.4)$ \\
\hline Serum albumin level $<3.5 \mathrm{~g} / \mathrm{dL}$ & $49(58.3)$ & V & $23(27.4)$ \\
\hline Glucose $\geq 250 \mathrm{mg} / \mathrm{dL}$ & $5(6)$ & SMART-COP groups & \\
\hline Sodium<130 mmol/L & $4(4.8)$ & 1 & $38(45.2)$ \\
\hline High blood urea nitrogen levelc & $15(17.9)$ & 2 & $17(20.2)$ \\
\hline Hematocrit<30\% & $3(3.6)$ & 3 & $11(13.1)$ \\
\hline Serum C-reactive protein level $\geq 10 \mathrm{mg} / \mathrm{dL}$ & $56 / 61(91.8)$ & 4 & $18(21.4)$ \\
\hline Procalcitonin $\geq 0.25 \mathrm{ng} / \mathrm{mL}$ & $2 / 9(22.2)$ & & \\
\hline \multicolumn{4}{|l|}{$\begin{array}{l}\text { aRefers to } 84 \text { patients unless stated otherwise. } \\
\text { bLook at Tables } 2-4 \text { for scoring } \\
{ }^{\text {'SpO }}{ }_{2} \leq 93 \% \text { (for patients }<50 \text { years old) }\end{array}$} \\
\hline
\end{tabular}

The PSI and CURB-65 systems are described to be ineffective in predicting the need for IRVS (27). Kontou et al. (29) reported the sensitivity, specificity, and positive and negative predictive values of PSI (classes IV and V) on predicting the need for IRVS as $81 \%, 50 \%, 28 \%$, and $91 \%$; those of PSI (class V) as 45\%, 83\%, 40\%, and 90\%; and those of CURB65 ( $\geq 2$ points) as $58 \%, 79 \%, 40 \%$, and $89 \%$, respectively. A study from
France stated that the PSI and CURB-65 systems work well in predicting the mortality and that the SMART-COP system is better at predicting the need for IRVS (32). The sensitivity, specificity, and positive and negative predictive values of SMART-COP ( $\geq 3$ points) in predicting the need for IRVS were reported as $92.3 \%, 62.3 \%$, $22 \%$ and $98.6 \%$, respectively. The PSI and CURB-65 systems were less effective with $74 \%$ and 
$39 \%$ sensitivity and $48 \%$ and $74 \%$ specificity, respectively. The SMARTCOP system is reported to work well for patients who were directly hospitalized into the ICU and for those who were transferred from the general wards (13). In a recent study, PSI was found to be successful in predicting the 30-day mortality compared with the SMART-COP system with AUC values of 0.78 and 0.69 , respectively, and the SMARTCOP system was the most effective in predicting the need for IRVS (AUC 0.73) (31). Davis et al. (30) reported the sensitivity of SMART-COP ( $\geq 3$ points) in predicting the need for IRVS as $71 \%$. In our study, the

Table 6. 30-day mortality and the need for IRVS according to groups of three scoring systems

\begin{tabular}{|c|c|c|c|}
\hline & $n=84$ & $\begin{array}{l}\text { Need for } \\
\text { IRVS } \\
\text { n (\%) }\end{array}$ & $\begin{array}{c}\text { 30-day } \\
\text { mortality } \\
\text { n (\%) }\end{array}$ \\
\hline \multicolumn{4}{|c|}{ CURB-65 groups } \\
\hline 1 & 52 & $1(1.9)$ & $0(0)$ \\
\hline 2 & 16 & $4(25)$ & $1(6.3)$ \\
\hline 3 & 16 & $9(56.3)$ & $5(31.3)$ \\
\hline \multicolumn{4}{|c|}{ PSI classes } \\
\hline 1 & 16 & $0(0)$ & $0(0)$ \\
\hline II & 19 & $0(0)$ & $0(0)$ \\
\hline III & 8 & $0(0)$ & $0(0)$ \\
\hline IV & 18 & $1(5.6)$ & $0(0)$ \\
\hline V & 23 & $13(56.5)$ & $6(26.1)$ \\
\hline \multicolumn{4}{|c|}{ SMART-COP groups } \\
\hline 1 & 38 & $0(0)$ & $0(0)$ \\
\hline 2 & 11 & $1(5.9)$ & $0(0)$ \\
\hline 3 & 17 & $2(18.2)$ & $1(9.1)$ \\
\hline 4 & 18 & $11(61.1)$ & $5(27.8)$ \\
\hline \multicolumn{4}{|c|}{$\begin{array}{l}\text { IRVS: Intensive respiratory and vasopressor support; PSI: pneumonia } \\
\text { severity index }\end{array}$} \\
\hline
\end{tabular}

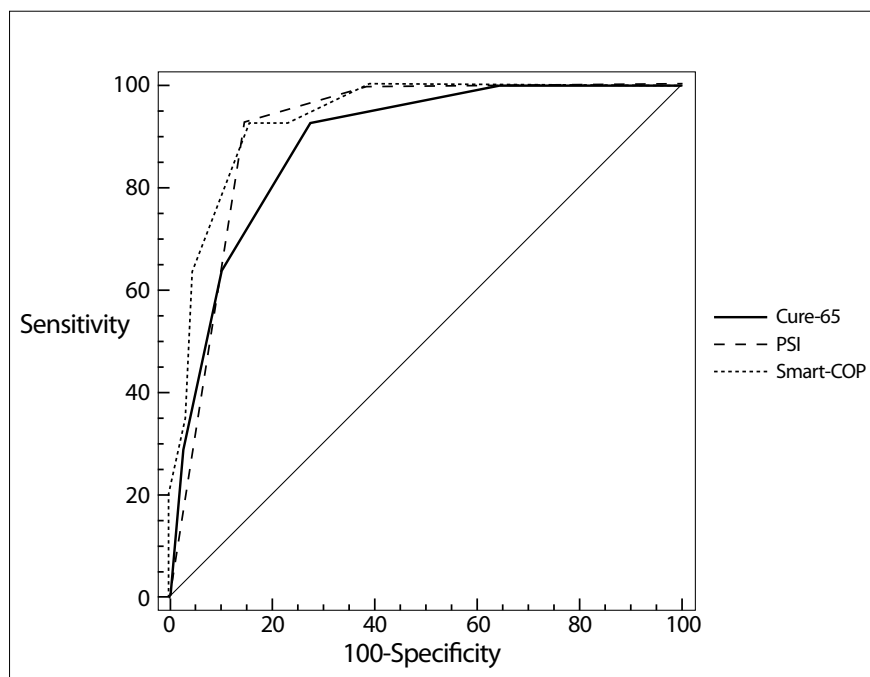

Figure 1. ROC analysis of scoring systems on the need for IRVS

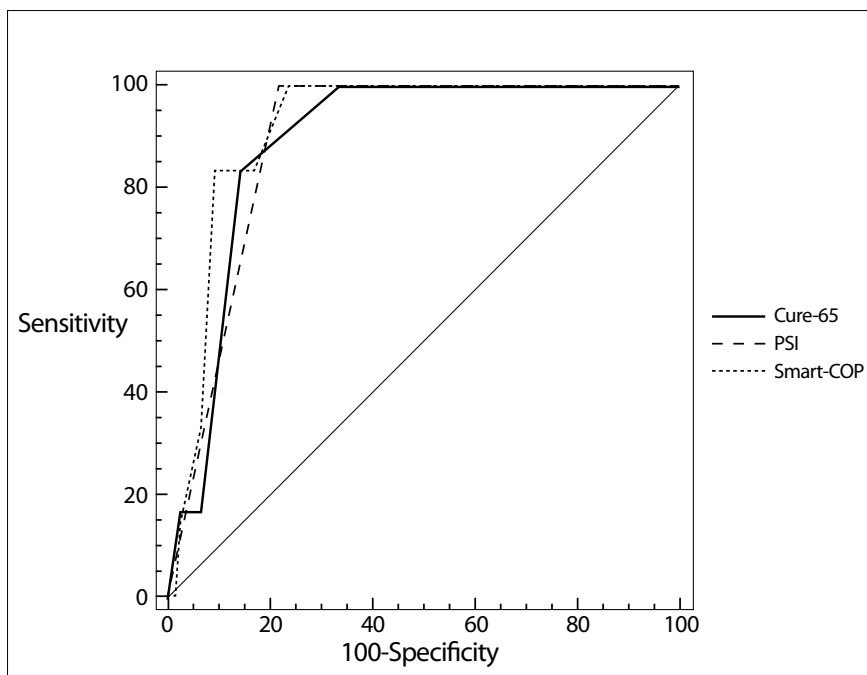

Figure 2. ROC analysis of scoring systems on 30-day mortality

Table 7. Compared yields of scoring systems on the need for IRVS

\begin{tabular}{|l|c|c|c|c|c|c|} 
& Sensitivity & Specificity & PPV & NPV & AUC & p value \\
\hline CURB-65 group 3 & 64.2 & 90 & 56.3 & 92.6 & 0.887 & $<0.01$ \\
PSI classes IV and V & 92.8 & 85.7 & 56.5 & 98.4 & 0.915 & $<0.01$ \\
SMART-COP $\geq 3$ points & 100 & 54.2 & 30.4 & 100 & 0.937 & $<0.01$ \\
\hline
\end{tabular}

AUC: Area under the curve; NPV: negative predictive value; PPV: positive predictive value; PSI: pneumonia severity index

Table 8. Compared yields of scoring systems on 30-day mortality

\begin{tabular}{|l|c|c|c|c|c|c|} 
& Sensitivity & Specificity & PPV & NPV & AUC & p value \\
CURB-65 group 3 & 83.3 & 85.9 & 31.2 & 98.5 & 0.890 & $<0.01$ \\
PSI classes IV and V & 100 & 78.2 & 26.1 & 100 & 0.891 & $<0.01$ \\
SMART-COP $\geq 3$ points & 100 & 48.7 & 13.0 & 100 & 0.918 & $<0.01$ \\
\hline
\end{tabular}

AUC: Area under the curve; NPV: negative predictive value; PPV: positive predictive value; PSI: pneumonia severity index 
values for PSI and CURB-65 in predicting the need for IRVS were more accurate than other comparable studies, but the values for SMARTCOP were similar to those reported in the literature (13). Although the SMART-COP system was specifically designed to predict the need for IRVS, we did not observe this difference in our study, possibly because of the relatively low number of cases.

In some studies, the need for IRVS was found to be $27 \%-37 \%$ within the low risk classes of PSI (classes I-III) (33-36). In our study, no requirement for IRVS was observed in PSI classes I-III and the low risk group of SMART-COP ( $<3$ points), but one patient in CURB-65 group 1 and four patients in group 2 were followed-up in the ICU.

The main limitation of this study was the number of the included patients, which is relatively low to achieve a reliable conclusion. This may be partly because of strictly followed exclusion criteria.

In this paper, we compared the yields of three severity scores in CAP, but we do believe that the doctors should not search for a "crystal ball" to see the prognosis of a patient or a "magic wand" to heal. We agree with Dr. Filipe Froes; these scores cannot or should not substitute a detailed professional evaluation by an experienced physician (SMARTDOCTORS), rather, are useful supplementary information (37).

\section{CONCLUSION}

The CURB-65, PSI, and SMART-COP scoring systems used to predict mortality and the need for IRVS were all found to be equally effective for this purpose in this study. The mortality and the need for IRVS are usually high in some studies that were conducted to compare scoring systems, possibly because of the inclusion criteria. Although more reliable scoring systems are proposed, clinical assessments are still crucial to predict CAP disease mortality and the requirement for IRVS.

Ethics Committee Approval: Ethics committee approval was received for this study from the ethics committee of Atatürk Chest Diseases and Thoracic Surgery Training and Research Hospital.

Informed Consent: A written informed consent form was obtained from every patient.

Peer-review: Externally peer-reviewed.

Author contributions: Concept - I.O.A, N.Ç., A.E.; Design - N.Ç., A.E.; Supervision - N.Ç., A.E.; Resource - I.O.A., A.E.; Materials - I.O.A., N.Ç.; Data Collection and/or Processing - I.O.A., A.E.; Analysis and/or Interpretation - I..O.A., N.Ç., A.E.; Literature Search - I.O.A., A.E.; Writing - I.O.A, N.Ç., A.E.; Critical Reviews - A.E., N.Ç.

Acknowledgements: Ibrahim Onur ALICI, MD is the guarantor of the scientific statements of the paper.

Conflict of Interest: No conflict of interest was declared by the authors.

Financial Disclosure: The authors declared that this study has received no financial support.

\section{REFERENCES}

1. T.C. Sağlık Bakanlığı, Refik Saydam Hıfzıssıhha Merkezi Başkanlığı Hıfzıssıhha Mektebi Müdürlüğü, Başkent Üniversitesi Ulusal Hastalık Yükü ve Maliyeti Etkinlik Projesi, 2004 (www.toraks.org.tr).

2. Acute respiratory infections in under-fives: $\mathbf{1 5}$ million deaths a year. Lancet 1985; 2: 699-701.
3. Centers for Disease Control and Prevention (CDC). Introduction to Table V. Premature deaths, monthly mortality and monthly physician contacts: United States. MMWR Morb Mortal Wkly Rep 1997; 46: 556-61.

4. Pio A, Leowski J, Luelmo F. Epidemiological magnitude of the problem of acute respiratory infections in children in developing countries. Bull IUAT 1983; 58: 199-204.

5. Pinner RW, Teutsch SM, Simonsen L, Klug LA, Graber JM, Clarke MJ, et al. Trends in infectious diseases mortality in the United States. JAMA 1996; 275: 189-93. [CrossRef]

6. Marston BJ, Plouffe JF, File TM Jr, Hackman BA, Salstrom SJ, Lipman HB, et al. Incidence of community-acquired pneumonia requiring hospitalization. Results of a population-based active surveillance Study in Ohio. The Community-Based Pneumonia Incidence Study Group. Arch Intern Med 1997; 157: 1709-18. [CrossRef]

7. Guest JF, Morris A. Community-acquired pneumonia: the annual cost to the the National Health Service in the UK. Eur Respir J 1997; 10: 1530-4. [CrossRef]

8. Niederman MS, McCombs JS, Unger AN, Kumar A, Popovian R. The cost of treating community-acquired pneumonia. Clin Ther 1998; 20: 820-37. [CrossRef]

9. Jackson ML, Neuzil KM, Thompson WW, Shay DK, Yu O, Hanson CA, et al. The burden of community acquired pneumonia in seniors: results of a population-based study. Clin Infect Dis 2004; 39: 1642-50. [CrossRef]

10. Almirall J, Bolibar I, Vidal J, Sauca G, Coll P, Niklasson B, et al. Epidemiology of community-acquired pneumonia in adults: a population-based study. Eur Respir J 2000; 15: 757-63. [CrossRef]

11. Fine MJ, Auble TE, Yealy DM, Hanusa BH, Weissfeld LA, Singer DE, et al. A prediction rule to identify low-risk patients with community acquired pneumonia. N Engl J Med 1997; 336: 243-50. [CrossRef]

12. Lim WS, van der Eerden MM, Laing R, Boersma WG, Karalus N, Town Gl, et al. Defining community acquired pneumonia severity on presentation to hospital: an international derivation and validation study. Thorax 2003; 58: 377-82. [CrossRef]

13. Charles PG, Wolfe R, Whitby M, Fine MJ, Fuller AJ, Stirling R, et al. SMARTCOP: a tool for predicting the need for intensive respiratoy or vasopressor support in community-acquired pneumonia. Clin Infect Dis 2008; 47: 375-84. [CrossRef]

14. Türk Toraks Derneği Erişkinlerde Toplumda Gelişen Pnömoni Tanı ve Tedavi Uzlaşı Raporu Turkish Thoracic Journal 2009; 10; Supplement.

15. Capelastegui A, Espana PP, Quintana JM, Areitio I, Gorordo I, Egurrola M, et al. Validation of a predictive rule for the management of community-acquired pneumonia. Eur Resp J 2006; 27: 151-7. [CrossRef]

16. Bauer TT, Ewig S, Marre R, Suttorp N, Welte T; CAPNETZ Study Group. CRB-65 predicts death from community-acquired pneumonia. J Intern Med 2006; 260: 93-101. [CrossRef]

17. Chalmers JD, Singanayagam A, Hill AT. Predicting the need for mechanical ventilation and/or inotropic support for young adults admitted to the hospital with community-acquired pneumonia. Clin Infect Dis 2008; 47: 1571-4. [CrossRef]

18. Chalmers JD, Singanayagam A, Hill AT. Systolic blood pressure is superior to other haemodynamic predictors of outcome in community acquired pneumonia. Thorax 2008; 63: 698-702. [CrossRef]

19. Akpınar S, Rollas K, Akpınar EE, Alagöz A, Uçar N, Şipit YT. Effect of the presence of pneumonia on noninvasive ventilation success in chronic obstructive pulmonary disease cases with acute hypercapnic respiratory failure. Turk J Med Sci 2013; 43: 373-8.

20. Köksal I, Ozlü T, Bayraktar O, Yılmaz G, Bülbül Y, Oztuna F, et al. Etiological agents of community-acquired pneumonia in adult patients in Turkey; a multicentric, cross-sectional study. Tuberk Toraks 2010: 58; 119-27.

21. Marrie TJ, Huang JQ. Low-risk patients admitted with community-acquired pneumonia. Am J Med 2005; 118: 1357-63. [CrossRef]

22. Labarere J, Stone RA, Scott Obrosky D, Yealy DM, Meehan TP, Auble TE, et al. Factors associated with the hospitalization of low-risk patients with community-acquired pneumonia in a cluster-randomized trial. J Gen Intern Med 2006; 21: 745-52. [CrossRef] 
23. Espana PP, Capelastegui A, Quintana JM, Bilbao A, Diez R, Pascual S, et al. Validation and comparison of SCAP as a predictive score for identifying low-risk patients in community-acquired pneumonia. J Infect 2010; 60: 106-13. [CrossRef]

24. Aujesky D, Auble TE, Yealy DM, Stone RA, Obrosky DS, Meehan TP, et al. Prospective comparison of three validated prediction rules for prognosis in community-acquired pneumonia. Am J Med 2005; 118: 384-92. [CrossRef]

25. Man SY, Lee N, Ip M, Antonio GE, Chau SS, Mak P, et al. Prospective comparison of three predictive rules for assessing severity of community-acquired pneumonia in Hong Kong. Thorax 2007; 62: 348-53. [CrossRef]

26. Buising KL, Thursky KA, Black JF, MacGregor L, Street AC, Kennedy MP, et al. A prospective comparison of severity scores for identifying patients with severe community acquired pneumonia: reconsidering what is meant by severe pneumonia. Thorax 2006; 61: 419-24. [CrossRef]

27. Niederman MS. Making sense of scoring systems in community-acquired pneumonia. Respirology 2009; 14: 327-35. [CrossRef]

28. Niederman MS, Feldman C, Richards GA. Combining information from prognostic scoring tools for CAP: an American view on how to get the best of both worlds. Eur Resp J 2006; 27: 9-11. [CrossRef]

29. Kontou P, Kuti JL, Nicolau DP. Validation of the Infectious Diseases Society of America/American Thoracic Society criteria to predict severe community-acquired pneumonia caused by Streptococcus pneumoniae. Am J Emer Med 2009; 27: 968-74. [CrossRef]

30. Davis JS, Cross GB, Charles PG, Currie BJ, Anstey NM, Cheng AC. Pneumonia risk stratification in tropical Australia: does the SMART-COP score apply? Med J Aust 2010; 192: 133-6.
31. Muller MP, McGeer AJ, Hassan K, Marshall J, Christian M; Toronto Invasive Bacterial Disease Network. Evaluation of pneumonia severity and acute physiology scores to predict ICU admission and mortality in patients hospitalized for influenza. PLoS One 2010; 5: e9563. [CrossRef]

32. Bui HN, Vargas F, Gruson D, Hilbert $G$. Where to manage community acquired pneumonia? The assessment of severity. Rev Mal Respir 2011; 28: 240-53. [CrossRef]

33. Ewig S, de Roux A, Bauer T, García E, Mensa J, Niederman M, et al. Validation of predictive rules and indices of severity for community acquired pneumonia. Thorax 2004; 59: 4217. [CrossRef]

34. Angus DC, Marrie TJ, Obrosky DS, Clermont G, Dremsizov TT, Coley C, et al. Severe community-acquired pneumonia: use of intensive care services and evaluation of American and British Thoracic Society diagnostic criteria. Am J Respir Crit Care Med 2002; 166: 717-23. [CrossRef]

35. Valencia M, Badia JR, Cavalcanti M, Ferrer M, Agustí C, Angrill J, et al. Pneumonia severity index class $\vee$ patients with community-acquired pneumonia: characteristics, outcomes, and value of severity scores. Chest 2007; 132: 515-22. [CrossRef]

36. Restrepo MI, Mortensen EM, Velez JA, Frei C, Anzueto A. A comparative study of community-acquired pneumonia patients admitted to the ward and the ICU. Chest 2008; 133: 610-7. [CrossRef]

37. Froes F. PSI, CURB-65, SMART-COP or SCAP? And the winner is... SMART-DOCTORS (Editorial). Rev Port Pneumol 2013; 19: 243-4. [CrossRef] 